\title{
Colpocleisis, patient satisfaction and quality of life
}

\author{
Kolpokleisis, hasta memnuniyeti ve yaşam kalitesi \\ Mehmet Reşit Asoğlu, Selçuk Selçuk, Çetin Çam, Reyhan Ayaz, Niyazi Tuğ, Ateş Karateke \\ Department of Gynecology and Obstetrics, Zeynep Kamil Training and Research Hospital, Istanbul, Turkey
}

\section{Abstract}

Objective: The aim of this study was to investigate the impact of colpocleisis operations with or without an anti-incontinence procedure on post-operative objective and subjective outcomes.

Material and Methods: Partial and total colpocleisis cases, with or without concomitant trans-obturator tension-free (TOT) procedure, were analyzed retrospectively. Pre- and post-operative POP-Q, urodynamics, UDI 6 and IIQ 7 scores and the level of patient satisfaction were the outcome measures.

Results: A total of 27 patients with colpocleisis (23 partial and 4 total) were analyzed. Seven women underwent also a concomitant TOT procedure. Of the patients, $66.7 \%, 25.9 \%$ and $7.4 \%$ were 'very satisfied', 'satisfied' and 'not satisfied', respectively. UDI-6 and IIQ-7 scores were improved in all patients. Post-operative urinary retention was not observed and prolapse recurred in one patient.

Conclusion: In elderly or medically compromised patients with advanced pelvic organ prolapse, colpocleisis is a safe and effective surgical technique with a high subjective satisfaction rate. A concomitant TOT procedure may be added where indicated.

(J Turkish-German Gynecol Assoc 2012; 13: 253-6)

Key words: Colpocleisis, transobturatuar tape, pelvic organ prolapse, quality of life, patient satisfaction

Received: 02 August, 2012

Accepted: 20 September, 2012
Özet

Amaç: $\mathrm{Bu}$ çalışmanın amacı, kolpoklesis operasyonu \pm antiinkontinans prosedürünün post-operatif objektif ve subjektif sonuçlara etkisini araştırmaktır.

Gereç ve Yöntemler: Parsiyel ve total kolpokleisis operasyonu \pm transobturatuar tape prosedürü (TOT) uygulanan olgular retrospektif olarak analiz edildi. Pre-operatif ve post-operatif POP-Q, ürodinami, UDI-6 ve IIQ-7 skorları, hasta memnuniyeti seviyeleri değerlendirildi.

Bulgular: Kolpokleisis operasyonu (23 parsiyel ve 4 total) yapılan toplam 27 hasta değerlendirildi. Yedi hastaya eş zamanlı TOT prosedürü uygulandı. Hastaların; \%66.7'si çok memnun, \%25.9'u memnun, \%7.4'i memnun değildi. Bütün hastalarda UDI-6 ve IIQ-7 skorlarında iyleşme oldu. Hastaların hiçbirinde post-operatif üriner retansiyon izlenmedi ve sadece bir hastada prolapsus nüks etti.

Sonuç: İleri derece pelvik organ prolapsusu olan yaşlı hastalarda veya medikal olarak düşkün hastalarda, yüksek subjektif başarı oranı ile kolpokleisis güvenli ve etkili bir cerrahi tekniktir. Endike olduğu durumlarda eş zamanlı TOT prosedürü eklenebilir.

(J Turkish-German Gynecol Assoc 2012; 13: 253-6)

Anahtar kelimeler: Kolpokleisis, transobturatuar tape, pelvik organ prolapsusu, yaşam kalitesi, hasta memnuniyeti

Geliş Tarihi: 02 Ağustos 2012

Kabul Tarihi: 20 Eylül 2012

\section{Introduction}

Life expectancy is increasing, and consequently there are growing number of elderly women with lower urinary tract symptoms (LUTS) who also suffer from other chronic medical conditions (1). Surgery is one of the main options for advanced prolapse but it carries an inherent risk for re-operation for up to one-third (2). Therefore, it is important to select an optimal surgical technique with high operative success and low risk of complications in these elderly, fragile women with increased peri-operative risks and complications. In women who do not wish to maintain their vaginal coital function, obliterative procedures such as colpocleisis may be the management of choice (1).

Not much is known about management of the LUTS at the time of colpocleisis. Although a concomitant anti-incontinence procedure is suggested to prevent new onset post- operative urinary incontinence, it has been proposed that the weakened detrusor muscle function commonly seen in these elderly women may lead to urinary retention (3-6).

In this study, we retrospectively analyzed the impact of colpocleisis, with or without an anti-incontinence procedure, on post-operative objective and subjective outcomes.

\section{Material and Methods}

\section{Study design and patients selection}

Data collected from a total of 27 patients who underwent total or partial colpocleisis operations in a tertial referral pelvic reconstructive surgery clinic between 2005 and 2009 were analyzed.

\section{Pre-/post-operative evaluation}

All the patients underwent a standard preoperative evaluation, including cervical smear, endometrial sampling, transvaginal 
and renal ultrasonography. The assessment of the prolapse was performed by the principal author (A.K) using the Pelvic Organ Prolapse Quantification (POP-Q) scoring system (7). Pre- and post-operative symptoms and complaints were assessed using the validated versions of the short forms of the Urinary Distress Inventory (UDI-6) and the Incontinence Impact Questionnaire (IIQ-7) (8). Subjective satisfaction of the patient was classified as 'very satisfied', 'satisfied', 'not satisfied' and 'regret'.

All patients underwent urodynamic evaluation (filling cystometry) pre-and post-operatively. Urodynamic evaluations were performed in accordance with criteria established by the International Continence Society (9). To detect masked stress incontinence (SUI), pre-operative urodynamic testing was performed with the reduction of the prolapsed segment(s) by using ring forceps without any possible compression to the urethra.

\section{Surgical Methods}

All the operations were performed by the principal author (A.K.)

\section{Partial Colpocleisis}

Rectangular portions of the anterior and posterior vaginal walls were dissected off the underlying fibromuscular tissue, leaving a lateral 2-cm bridge of vaginal mucosa. Special care was taken not to involve the area beneath the urethra. Lateral vaginal canals were created and the anterior and posterior fibromuscular tissue compartments were approximated by delayed absorbable interrupted sutures.

\section{Total Colpocleisis}

In hysterectomized patients the vaginal epithelium was completely dissected off as the canals were not necessary. According to the surgeon's preference, levator myorrhaphy and/or perineorrhaphy were performed.

Patients with urodynamic stress incontinence (USI) also underwent a concomitant transobturator procedure.

Post-operatively, post void residue (PVR) measurements less than $100 \mathrm{~mL}$ were considered as normal.

\section{Statistical analysis}

All values were given as mean \pm standard deviation. Statistical analysis was performed using SPSS 11.5 software. Student's T, and Paired $\mathrm{T}$ tests were performed as appropriate; $\mathrm{p}=0.05$ was accepted as the degree of significance.

\section{Results}

Data from 27 patients were eligible for the study. Demographic data of the patients are presented in Table 1 and operative data are given in Table 2. The mean post-operative follow-up period was $27.5 \pm 13.7$ ( $\min 12$, max 78$)$ months. One patient had a history of vaginal hysterectomy for uterine prolapse. The remaining 26 patients did not report any operation for prolapse. One patient with partial colpocleisis received local anesthesia and the remaining 26 operations were performed under spinal anesthesia. After excluding additional operations, mean opera-
Table 1. Demographic data of the patients $(n=27)$

\begin{tabular}{|l|c|}
\hline BMI $\left(\mathrm{kg} / \mathrm{m}^{2}\right)$ mean \pm sd & $26.70 \pm 3.94$ \\
\hline Age (years) mean \pm sd & $72.85 \pm 6.12$ \\
\hline Parity (n) mean \pm sd & $4.70 \pm 2.39$ \\
\hline Diabetes Mellitus & 33.3 \\
\hline$\%$ & $(9)$ \\
\hline (n) & \\
\hline Hypertension & 51.9 \\
\hline$\%$ & $(14)$ \\
\hline (n) & \\
\hline Stage III Prolapse & 7.4 \\
\hline$\%$ & $(2)$ \\
\hline (n) & \\
\hline Stage IV Prolapse & 92.6 \\
\hline$\%$ & $(25)$ \\
\hline (n) & \\
\hline Prior hysterectomy & 3.7 \\
\hline$\%$ & $(1)$ \\
\hline (n) & \\
\hline BMI: Body Mass Index & \\
\hline
\end{tabular}

Table 2. Operative data of the patients $(n=27)$

\begin{tabular}{|l|c|}
\hline \multicolumn{2}{|l|}{ Partial Colpocleisis } \\
\hline$\%$ & 85.2 \\
\hline (n) & $(23)$ \\
\hline Total Colpocleisis \\
\hline$\%$ & 14.8 \\
\hline (n) & $(4)$ \\
\hline Concomitant TOT & 25.9 \\
\hline$\%$ & $(7)$ \\
\hline (n) & \\
\hline Concomitant Hysterectomy & 11.1 \\
\hline$\%$ & $(3)$ \\
\hline (n) & \\
\hline Hospitalization (days) & $2.4 \pm 0.6$ \\
\hline mean \pm sd \\
\hline TOT: trans-obturator tension-free \\
\hline
\end{tabular}

tion times of partial and total colpocleisis were $25.4 \pm 1.78$ and $60 \pm 5$ minutes, respectively. No major per-operative complication was recorded.

Preoperatively, seven patients (25.9\%) were diagnosed as having USI and ten (37.1\%) women had urodynamical findings of detrusor overactivity (DOA). Postoperatively, $11 \%(3 / 27)$ of patients had symptoms of SUI. Persistence of USI was recorded 
in one patient who underwent concomitant TOT procedure and two patients without this anti-incontinence procedure were diagnosed as de novo USI after colpocleisis. 18.5\% (5/27) of patients had DOA, postoperatively. No patient showed urodynamical findings of DOA postoperatively. Anatomical success was evident in $96.3 \%$ (26/27) patients but in one patient, recurrence of prolapse was diagnosed with the leading point of the prolapsed segment three centimeters beyond the hymenal ring. No patient in the postoperative period had a PVR value greater than $100 \mathrm{~mL}$, whereas the rate of patients with elevated preoperative PVR value was $22 \%(6 / 27)$.

Pre and post-operative mean total scores of IIQ 7 were $15.07 \pm 2.18$ and, $2.67 \pm 4.09$, respectively, in all patients. This difference was statistically significant $(\mathrm{p}<0.0001)$. In 20 patients without any concomitant anti-incontinence procedure, total IIQ-7 scores and irritative, stress and obstructive subscores of UDI-6 were lower in the postoperative period, compared to the preoperative assessment. These improvements were statistically significant in IIQ-7 scores and in the obstructive subscore of UDI-6 ( $<<000.1)$ (Table 3 ).

In 7 patients with concomitant TOT procedure, total IIQ-7 scores and irritative, stress and obstructive subscores of UDI-6 were lower in the postoperative period, compared to preoperative assessment $(15.14 \pm 2.27$ to $3.14 \pm 5.37,3.00 \pm 1.00$ to $1.29 \pm 1.11,5.43 \pm 0.79$ to $1.00 \pm 2.24$ and $2.14 \pm 1.22$ to $0.29 \pm 0.49$; respectively). No statistical calculation was performed.

Among all participants, 92.6\% (25/27) were satisfied ((66.7\% (18/27) and 5.9\% (7/27) 'very satisfied' and 'satisfied', respectively) with the operations. Two (7.4\%) patients reported having feelings of regret, one because of the recurrence of her prolapse and incontinence, and the other because of the new onset of stress incontinence.

\section{Discussion}

This retrospective study showed that women who underwent colpocleisis operations were satisfied with the results of their management. The satisfaction rate was over $90 \%$, with an anatomical success rate over 95\%, which is consistent with previously reported anatomical success rates between $91 \%$ and $100 \%(3,5,10-12)$. Furthermore, this study provided some data about the improvement in their quality of life (QoL) using validated condition-specific instruments for pelvic floor symptoms.

Table 3. Comparison of pre-and post-operative UDI-6 subscores and IIQ-7 scores of patients without any additional incontinence operation

\begin{tabular}{|l|c|c|c|}
\hline & $\begin{array}{c}\text { Pre-operative } \\
\text { (mean } \pm \text { sd) }\end{array}$ & $\begin{array}{c}\text { Post-operative } \\
\text { (mean } \pm \text { sd) }\end{array}$ & $\mathbf{p}$ \\
\hline UDI-6 irritative & $1.70 \pm 1.49$ & $1.65 \pm 1.42$ & 0.914 \\
\hline UDI-6 stress & $1.65 \pm 1.78$ & $0.95 \pm 1.54$ & 0.192 \\
\hline UDI-6 obstructive & $2.85 \pm 1.95$ & $0.35 \pm 0.59$ & 0.000 \\
\hline IIQ 7 & $15.05 \pm 2.21$ & $2.50 \pm 3.69$ & 0.000 \\
\hline
\end{tabular}

UDI-6: Urinary Distress Inventory, IIQ-7 Incontinence Impact Questionnaire
For women with bothersome symptoms, surgical therapy is an effective option. Treatment choice depends on age and medical co-morbidities, desire for sexual function and risk factors for recurrence. The main goal should be to improve the QoL of the sufferers and the benefits of the management should always outweigh the risks. Anatomical success may satisfy the surgeon but little is known about the impact of colpocleisis on patient satisfaction and on their LUTS. Shortage of this information limits the clinicians in counselling the patients to consider colpocleisis for their prolapse.

Trouble with stress incontinence and/or urge symptoms is common in these patients (13). In this study, IIQ-7 and UDI-6 questionnaires, which were both developed and combined to assess the impact of urinary incontinence on QoL, were used to measure this . Our retrospective cohort consisted of two groups of patients, one with colpocleisis and other with concomitant TOT procedure. Unfortunately, this retrospective study was not powered to assess the efficacy of an added anti-incontinence procedure. Although Total IIQ-7 scores and irritative, stress and obstructive subscores of UDI-6 were lower in the postoperative period in these patients, compared to preoperative assessment, with such small numbers it was impossible to draw any conclusion or make any statistics. On the other hand, when all patients are considered as a whole, pre and post-operative mean total scores of IIQ-7 were significantly better, showing a clear benefit from colpocleisis whether an anti-incontinence procedure is added or not. This improvement in QoL was also evident in the Total IIQ-7 score and the obstructive subscore of UDI- 6 of patients without any concomitant anti-incontinence procedure. It is known that patients with advanced POP show a high rate of urinary retention secondary to compromised urethral flow. Adding anti-incontinence surgery in these patients may raise concerns about worsening o fthe obstructed urinary outflow, but adequate repair of the prolapse resolves the obstruction (6). One fifth of our cohort had preoperative PVR values greater than 100 mL but no patient had a PVR value suggesting outflow obstruction in the postoperative period. These data may be interpreted as being in agreement with the findings that colpocleisis and concomitant mid-urethral sling interventions improve urinary symptoms without causing significant urinary retention and may be offered to elderly women with SUI who are undergoing colpocleisis regardless of preoperative PVR (14). Even when no concomitant anti-incontinence operation is planned; we believe that special care has to be taken not to involve the area beneath the urethra for the possibility of a sling operation, in case de novo SUI occurs after the operation.

Although colpocleisis is offered to elderly women without sexual function, some concern exists that such an obliterative procedure which significantly alters female genital anatomy and vaginal function may adversely affect body image, cause patient dissatisfaction and give rise to feelings of regret about the treatment of their prolapse (13). The rate of regret after colpocleisis ranges between $3 \%$ and $10 \%$ and in this study only two (7.4\%) patients reported feelings of regret (15). However, it should be noted that these two patients were not mainly concerned about their lost sexual image, one reporting her reason of feelings of regret as recurrence of her prolapse and incon- 
tinence, and the other as new onset (de novo) stress incontinence. Overall, $92.6 \%$ of this retrospective cohort were satisfied (66.7\% and $5.9 \%$, 'very satisfied' and 'satisfied', respectively) with the operations.

\section{Conclusion}

Colpocleisis offers a safe and effective option in resolving prolapse and pelvic symptoms and improves the QoL of elderly, fragile women who do not seek vaginal coital function. It is associated with high patient satisfaction and most causes of regret can be corrected with re-operation. Although the number of concomitantly treated patients is insufficient to draw any firm conclusion in this study, it seems to work well when combined with a suburethral sling operation.

The number of older women seeking care for their prolapse is increasing and colpocleisis is becoming more important than ever. Nevertheless, further studies are still needed to establish the management of concomitant anti-incontinence surgery for overt or masked stress urinary incontinence.

\section{Conflict of interest}

No conflict of interest was declared by the authors.

\section{References}

1. FitzGerald MP, Richter HE, Siddique S, Thompson P, Zyczynski H; Ann Weber for the Pelvic Floor Disorders Network. Colpocleisis: a review. Int Urogynecol J Pelvic Floor Dysfunct 2006; 17: 261-71.[CrossRef]

2. Olsen AL, Smith VJ, Bergstrom JO, Colling JC, Clark AL. Epidemiology of surgically managed pelvic organ prolapse and urinary incontinence. Obstet Gynecol 1997; 89: 501-6.[CrossRef]

3. FitzGerald MP, Brubaker L. Colpocleisis and urinary incontinence. Am J Obstet Gynecol 2003; 189: 1241-4.[CrossRef]

4. Long CY, Hsu SC, Wu TP, Sun DJ, Su JH, Tsai EM. Urodynamic comparison of continent and incontinent women with severe uterovaginal prolapse. J Reprod Med 2004; 49: 33-7.
5. Abbasy S, Kenton K. Obliterative Procedures for Pelvic Organ Prolapse. Clin Obstet Gynecol. 2010; 53: 86-98. [CrossRef]

6. Fitzgerald MP, Kulkarni N, Fenner D. Postoperative resolution of urinary retention in patients with advanced pelvic organ prolapse. Am J Obstet Gynecol 2000; 183: 1361-4.[CrossRef]

7. Bump RC, Mattiasson A, Bø K, Brubaker LP, DeLancey JO, Klarskov $\mathrm{P}$, et al. The standardization of terminology of female pelvic organ prolapse and pelvic floor dysfunction. Am J Obstet Gynecol 1996; 175: 10-7. [CrossRef]

8. Cam C, Sakalli M, Ay P, Cam M, Karateke A. Validation of the short forms of the incontinence impact questionnaire (IIQ-7) and the urogenital distress inventory (UDI-6) in a Turkish population. Neurourol Urodyn 2007; 26: 129-33.[CrossRef]

9. Abrams P, Cardozo L, Fall M, Griffiths D, Rosier P, Ulmsten U, et al. The standardisation of terminology of lower urinary tract function: report from the Standardisation Sub-committee of the International Continence Society. Am J Obstet Gynecol 2002; 187: 116-26. [CrossRef]

10. Hanson GE, Keettel WC. The neugebauer-le fort operation. A review of 288 colpocleises. Obstet Gynecol 1969; 34: 352-7.

11. DeLancey JO, Morley GW. Total colpocleisis for vaginal eversion. Am J Obstet Gynecol 1997; 176: 1228-35.[CrossRef]

12. Hoffman MS, Cardosi RJ, Lockhart J, Hall DC, Murphy SJ. Vaginectomy with pelvic herniorrhaphy for prolapse. Am J Obstet Gynecol 2003; 189: 364-71.[CrossRef]

13. Fitzgerald MP, Richter HE, Bradley CS, Ye W, Visco AC, Cundiff GW, et al. Pelvic support, pelvic symptoms, and patient satisfaction after colpocleisis. Int Urogynecol J Pelvic Floor Dysfunct 2008; 19: 1603-9. [CrossRef]

14. Abbasy S, Lowenstein L, Pham T, Mueller ER, Kenton K, Brubaker L. Urinary retention is uncommon after colpocleisis with concomitant mid-urethral sling. Int Urogynecol J 2009; 20: 213-6. [CrossRef]

15. Wheeler TL 2nd, Richter HE, Burgio KL, Redden DT, Chen CC, Goode PS, et al. Regret, satisfaction, and symptom improvement: analysis of the impact of partial colpocleisis for the management of severe pelvic organ prolapse. Am J Obstet Gynecol 2005; 193: 2067-70. [CrossRef] 